\title{
Rapid Prototyping Technology in Bone Tissue Engineering
}

\section{Md Enamul Hoque ${ }^{1 *}$ and R.G.S.V Prasad ${ }^{2}$}

${ }^{1}$ Department of Mechanical, Materials and Manufacturing Engineering, University of Nottingham Malaysia Campus, JalanBroga, Semenyih, Selangor, Malaysia ${ }^{2}$ Biomedical and Pharmaceutical Technology Research Group, Nano Research for Advanced Materials, Bangalore, Karnataka, India

Tissue engineering/regenerative medicine promises to solve problems in organ transplantation crisis. Autogenous bone grafting is considered to be the gold standard for the treatment and management of bone defects like, craniofacial disorders and orthopedic conditions such as, fractures and nonunions. 3D polymeric scaffolds can mimic the natural extracellular matrix of bone. Designing a scaffold with the required properties is a key factor that governs the bone tissue engineering. Complex porous $3 \mathrm{D}$ structures are fabricated by various processes like, foaming [1], salt leaching [2], emulsification [3] etc. However, scaffolds fabricated by these conventional methods can only justify partial requirements of tissue engineering approaches. The major drawbacks of these procedures include lack of control in morphological characteristics like, pore shape, size,distribution and pore connectivity. One of the recent techniques that add complexity reminiscent of tissue engineering is RapidPrototyping (RP) technology, which arranges/deposits drops or fibres of polymeric materials in required geometry. RP technology helps in designing $3 \mathrm{D}$ parts which are built layer-by-layer based on a Computer AidedDesign (CAD) file [4-6]. By far, there are number of commercial RP techniques available for different materials. This technique is best suited to directly generate complex-shaped porous scaffolds with well controlled internal structures. The material choice is very flexible as long as it can produce osteogenic effect. One of the widely studied materials for bone tissue regeneration is powder based bioceramic like, HydroxyApatite (HA) [7]. In this method ceramic powder is printed with a binder solution (usually a polymer-based binder solution). This slurry is now deposited layer-by-layer according to the design producing 3D scaffolds. The scaffolds generated by this process can withstand high pressures of 22
$\mathrm{MPa}$, which is essential for bone tissue engineering. The cells are seeded onto the 3D scaffolds and nurtured until they are sufficiently grown. The cell construct (scaffold along with cells) can then be implanted to the defect site for the regeneration of the bone. Hence, RP technology can be considered to be an ideal process for fabricating bone tissue engineering scaffolds.

\section{References}

1. Mathieu LM, Mueller TL, Bourban PE, Pioletti DP, Muller R, et al. (2006) Architecture and properties of anisotropic polymer composite scaffolds for bone tissue engineering. Biomaterials 27:905-916.

2. Zeltinger J, Sherwood JK, Graham DA, Mueller R ,Griffith LG (2001) Effect of pore size and void fraction on cellular adhesion, proliferation, and matrix deposition. Tissue Eng 7:557-572.

3. Bohner M, Van Lenthe GH, Grunenfelder S, Hirsiger W, Evison R, et al., (2005) Synthesis and characterization of porous beta-tricalcium phosphate blocks. Biomaterials 26:6099-6105.

4. Bose S, Roy M, Bandyopadhyay A (2012) Recent advances in bone tissue engineering scaffolds. Trends Biotechnol 30:546-554.

5. Hoque ME, Chuan YL, Pashby I (2012) Extrusion based rapid prototyping technique-An advanced platform for tissue engineering scaffold fabrication. Biopolymers 97: 83-93.

6. Hoque ME, Chuan YL, Pashby I, Ang AMW, Idurus R (2011) Process Optimization to Improve the Processing of Poly(DL-Lactide-co-Glycolide) into 3D Tissue Engineering Scaffolds. International Federation for Medical and Biological Engineering Proceedings 35: 836-840.

7. Tadic D, Epple M (2004) A thorough physicochemical characterization of 14 calcium phosphate-based bone substitution materials in comparison to natural bone. Biomaterials 25: 987-994.
*Corresponding author: Md Enamul Hoque, Department of Mechanical, Materials and Manufacturing Engineering, University of Nottingham Malaysia Campus, Jalan Broga, Semenyih, Selangor, Malaysia, Tel: +6 0162690 62; E-mail: enamul.hoque@nottingham.edu.my

Received December 12 2013; Accepted December 12, 2013; Published December 20, 2013

Citation: Hoque ME, Prasad RGSV (2013) Rapid Prototyping Technology in Bone Tissue Engineering. J Appl Mech Eng 2: e124. doi:10.4172/2168-9873.1000e124

Copyright: (c) 2013 Hoque ME, et al. This is an open-access article distributed under the terms of the Creative Commons Attribution License, which permits unrestricted use, distribution, and reproduction in any medium, provided the original author and source are credited. 